\section{Magdalena Wysocka}

Uniwersytet Warmińsko-Mazurski

w Olsztynie

magdalena.wysocka@uwm.edu.pl

\section{Roman Lewandowski}

- corresponding author

Społeczna Akademia Nauk

rlewando@wp.pl

\title{
Key Competences of a Health Care Manager
}

\section{ABSTRACT}

Objective: The aim of the research was to construct a theoretical model of competences of managers employed in health care institutions in the Warmińsko-Mazurskie Voivodeship.

Methodology: The theoretical list of competences was based on the literature of the subject and the results developed during the workshop session with postgraduate students in the scope of management of healthcare entities. All respondents (266 persons) were health care workers and held managerial positions at various levels of organizations.

Findings: On the basis of the obtained results it can be stated that in the key competency model of the efficient manager dominates professional competence in the field of organization and management. These competences were also diagnosed with the greatest deficiencies that hinder effective work.

\section{Value Added:}

Results of the research enable the introduction of appropriate curricular content into the educational model of potential healthcare managers, hence improving management quality of medical organizations.

Keywords: competence, health care, model, manager, efficient actions.

JEL codes: M12, M53 


\section{Introduction}

Efficiency and effects of new management are determined by many variables, among which are human resources, more precisely - their quality. Special requirements are placed upon the management as it is their quality that influences the optimal use of other resources of the healthcare provider. In this paper, it has been assumed that competences of all employees are assets of human resources.

The term competences appeared in the literature of subject at the beginning of the 80s of the last century?. Richard Boyatzis, in his publication for the American Management Association, presented the basic characteristics of effective manager, among which he enlisted competences as a human potential leading to such a behaviour that contributes to satisfying of requirements of a given job within the organisational environment, which in turn yields the desired results (Czapla, 2005, p.37). From the explanation in the footnote, we can derive that qualifications are a more narrow term than competences, what means that qualifications are not enough to be competent in a given work, occupation or profession. According to M. Armstrong (2000, p. 241) competent people at a workplace are those who fulfil the expectation towards achieving specific results. In turn, T.J. Watson (2001, p. 236) writes that competent managers are those who can properly influence others to fulfil their duties.

The term competences is interdisciplinary and multidimensional, which results in different interpretations by different authors. In definitions, there is no discordance in general understanding of competences. The differences in interpretation usually concern components, their meaning in the whole competency wallet and the analytical plane. In this paper, the term competency is defined as in R. Walkowiak (2007, pp. 19-20) as a "benchmark set of knowledge, skills, personality traits, attitudes and behaviour directed at

1. Earlier, the term qualifications was used, now those are a component of competences - cf, among others, Walkowiak, 2007, p.19. 
efficient operation". Whereas the key competences mean those competences that every manager should display in practice regardless of organisation type and management level.

In design practice, competence lists are evaluated based on the desired levels, i.e. levels that ensure efficient operation. It is done by measuring the levels of competences displayed in practice and on that basis excess and deficiencies in individual competences are identified and written in the form of competence profiles.

Designing competences for any manager, workplace, role or function in an organisation is difficult, as in practice, there is a large variety of organisations and workplaces at different levels of management and different regional conditions connected, among others, with culture of a given place (Bellini et al., 2013). That variety is also present in healthcare facilities, as seen, among others, in M. Kautsch (2015, pp. 92-105) who says that in the Polish system "important are those facilities that do not operate for profit - public and non-public (whereas among the non-public the majority operates for profit)". In that context, we can say that although the general objective of healthcare facilities is providing healthcare services, different management types directed at obtaining the designated/accepted goals and different sets of managerial competences are effective depending on the type of the facility. This study is aiming at expanding the knowledge on key competences of healthcare managers in the Warmińsko-Mazurskie Voivodeship. The research was based on literature studies, ABC (20/80) and self-assessment methods.

\section{Competences of healthcare managers}

Interesting reflections on the competence of non-public healthcare management are presented by R. Jankowiak (2011, pp. 123-135). The author wonders who should stand at the top of the hierarchic pyramid in medical service institutions - whether it is an entrepreneur, manager or perhaps a specialist? On the basis of his own observations and managerial experi- 
ence, he is critical of the specialists at the top, who are often very prominent in terms of professional medical skills but lack managerial competence. The author justifies his criticism in the following way: at the top of the hierarchy there is often a medical specialist because he usually had the idea and was the initiator of the establishment of a new entity. If this is the case, then "he employs other specialists, thus creating functional and operating levels. It is easy to see that each of them deals with the task focusing on the details. In this case, there is a lack of people responsible for the strategic sphere (...)".

Similar dilemma is described by N. Edwards et al. (2003), who offer three solutions for consideration:

- eliminating any management engagement into clinical matters,

- focusing on improving the quality of healthcare managers,

- developing a habit for the managers to think like doctors and vice versa, as they can learn a lot from each other.

Despite the difficulty in modelling competences, design work is being undertaken to outline the competence profiles of efficient managers. There are two design approaches. The first, most commonly used, profiles of positions roles and levels of management in a particular organisation are designed. Those are very detailed projects and due to the specific nature of the organisation, they are difficult to adapt to other entities. In the second approach, generalised profiles for the job groups are developed, e.g. for managerial positions, regardless of the specific job title or level of management. In these designs, it is assumed that any manager, without regard to job title or level of management, should be equipped with the necessary set of managerial competences. Typically, to the set of competences constructed this way, competences specific to e.g. the industry in which the manager operates are added.

In the literature of the subject a number of competence models for managers employed in healthcare institutions can be encountered. Individual authors list different sets of competences, or they emphasise the validity of only some of them. For example, K.I. Littwin (2013, pp. 209-2012), analysing 
the roles of medical professionals (encompassing doctors and nurses as middle managers), states that these people are increasingly more often administrators, and hence managers, and their competence portfolio should include not only high medical competences, but also managerial knowledge and skills, for they are responsible for the results of the processes carried out in their organisational units. In the context of the author's analysis of the key competences of the medical professional - the manager, they can include knowledge and skills in the management of medical processes, the quality and safety of patients, medical personnel, costs, cultural values and norms, and the image of the hospital.

A very general list of competences is also presented by M. Furtak et al. (2010, p. 213) emphasising the importance of issues such as knowledge of management, finance, economics and law, which they consider essential for rational decision-making and more effective results. In turn, A. Kostecka (2016) lists eighteen competences of a modern healthcare professional, including professional, interpersonal, business and strategic thinking in the medical profession. The list of key competences was also presented by R. Jankowiak (2011, pp. 123-135). Based on the analysis of the tasks assigned to the healthcare manager, the author focuses on, among others, delegation of power and responsibilities, development of mission, vision and strategies, process management, marketing and finance, and human resources management.

The authors of other studies focus on emphasising the importance of "soft" - interpersonal skills. For example, E. Jakubek et al. (2012, pp. 167-182) pay special attention to communication skills and building trust that allow for correct relationships with patients and colleagues. Other authors, such as L.E. Swayne et al. (2012, p. 183) and R. Lewandowski (2011, p. 121) also refer to trust as an important social competence. For the latter author, the important determinants of efficiency and quality in healthcare are friendliness, honesty and predictability. The importance of psychosocial competences enabling effective management of oneself and other people is also mentioned by $\mathrm{M}$. Matecka et al. (2015, p. 294). 
A study of leadership behaviours conducted by A.M. Burak et al. (2016, pp. 57-58) shows that active leadership is an important competence of the healthcare operational manager. In the opinion of the researchers, the most important features of such leadership are the ability to cooperate, competence, ability to solve problems, ability to act quickly, relationship building skills, assertiveness, strategic thinking, ability to provide feedback and analytical thinking.

In turn, from nationwide research conducted by the Akademia Ochrony Zdrowia (Academy of Health Protection) (2015)² among the 1000 people in management positions in healthcare institutions, the highest rated competences were employee motivation, team management and interpersonal communication.

Competence preferences were also identified among postgraduate students in the field of healthcare management, most of them (out of 86 participants) completed medical studies in various fields (Rosińska 2013, p. 16). The research carried out by the author shows that in the opinion of the students organisational and legal issues, restructuring of the medical entities, risk management, strategic management, management of information systems and medical documentation are the most useful in their management work.

The key competences of healthcare managers in Poland mentioned above correspond in part to the list of competences presented in the world literature. For example, in the study by B. Ramirez et al. (2017) the list of competences is divided into five main domains: communication and relationship management, leadership, professionalism, knowledge of the health environment and healthcare, and business skills. In turn, A. Leotsakos et al. (2014, pp. 2-3) from the World Health Organization (WHO) have divided the leadership competences of healthcare organisations managers into three subsets: personal attributes, leadership skills, and executive skills. J.G. Calhoun et al. (2008, p. 378) also grouped competences in three areas. According to these

2.Test of management competences of Polish hospital staff. 2015. Akademia Ochrony Zdrowia (Academy of Health protection) - Edumetriq, Sopot; www.edumetriq.pl, access 10.05.2017. 
researchers, the most important competences are focused on transformational skills (e.g., analytical thinking, innovative and strategic thinking and performance orientation), executive skills (including organisational design, process management and responsibility) and human resource management skills (among others, building and managing teams, focus on personal and employee development and communication), whereas the managerial competency model at the executive level listed 50 competencies, including 23 personal, 11 interpersonal, 12 managerial and 4 marketing competences (Yen-Ju Lin et al., 2011, pp. 89-90).

\section{Assumptions and research procedure}

The aim of the study was to design a key competency model of healthcare manager. In pursuit of its realization, theoretical considerations and the empirical material collected in the research were analyzed. The object of the research was the model of key competences, while the subject were the persons performing managerial functions and preparing for these functions in healthcare institutions in the Warmińsko-Mazurskie Voivodeship. The research question was formulated in the form of the following question: What competences should the manager of an entity or a separate department of healthcare institutions in the Warmińsko-Mazurskie Voivodeship be equipped with? In order to address this main problem, the following specific problems were studied in the research:

- What kind of competences should a manager have in order to be capable to efficiently manage healthcare institutions in the Warmińsko-Mazurskie Voivodeship?

- What is the hierarchy of importance of those competences?

- What is the desired state of the key competences of a healthcare institution manager?

- What is the current state of key competences of healthcare institution managers? 
- What are the gaps in the key competences of healthcare institution managers?

Literature studies, ABC (20/80) and self-assessment methods were used for the research. Literature studies were necessary to build the theoretical model of a competent healthcare manager. This model contained 38 competences. Using the ABC method and in accordance with Pareto rules, a hierarchy of importance of particular competencies was established. The structure was verified by 266 students enrolled in postgraduate studies conducted in the years 2012-2014 and 2016/2017 at the Tadeusz Kotarbiński University of Information Technology and Management in Olsztyn ${ }^{3}$. In workshops, students designed desirable levels, self-assessed current states, and identified gaps in the competency levels for the model of an effective health manager.

\section{Research results}

Post-graduate students participating in the study occupied different positions in healthcare institutions in the Warmińsko-Mazurskie Voivodeship. Most represented was the medium management staff and senior charge nurses. A detailed overview of occupational workplaces is given in Table 1.

\section{Table 1. Occupational workplaces of study participants}

\begin{tabular}{|l|l|l|}
\hline \multirow{2}{*}{ Job title } & Structure \\
\cline { 2 - 3 } & Number & $\%$ \\
\hline Head doctor & 4 & 1.5 \\
\hline Deputy head doctor & 1 & 0.4 \\
\hline Director & 9 & 3.4 \\
\hline Deputy director & 13 & 4.9 \\
\hline Chief accountant & 7 & 2.5 \\
\hline
\end{tabular}

3.The study was carried out under the project Healthcare Manager - postgraduate studies for the management of medical entities (Project No. POKL.02.03.04-00-049/12-00). 


\begin{tabular}{|l|l|l|}
\hline Deputy chief accountant & 6 & 2.3 \\
\hline Head nurse & 15 & 5.6 \\
\hline Senior charge nurse & 81 & 30.5 \\
\hline Other (medium management staff) & 130 & 48.9 \\
\hline \multicolumn{1}{|c|}{ Total } & 266 & 100.0 \\
\hline
\end{tabular}

\section{Source: own research.}

Nearly every third medical worker involved in the workshop worked in large and small entities, and one in four in the medium ones (classification according to the number of employees). They were mostly public health institutions (83.5\%). The majority of them had medical education (73.3\%). Those employed in the administrative service (finance and administration of healthcare facilities) have also completed postgraduate studies, mainly in the areas of public procurement, accounting and internal auditing. The health workers participating in the study were experienced, as one in three (33.3\%) had a seniority of 6 to 10 years and $46.7 \%$ over 15 years. Among all respondents, women were predominant (79.9\%).

At the beginning of the workshops, students were presented with a list of 30 competences based on the literature of the subject. This list was the basis for the exchange of views and discussions conducted in five-person teams. Students - employees of healthcare institutions, using the descriptions of their jobs and on the basis of their own experience, defined the individual competences and modified, by deleting and adding, the received theoretical list of competences. A new set of 38 competencies of the healthcare manager (Table 2) was created from the lists of individual teams.

Table 2. List of competences of a healthcare manager

\begin{tabular}{|l|l|}
\hline No. & Competence name \\
\hline 1. & knowledge in behaviour on the healthcare market \\
\hline 2. & knowledge in management of finances \\
\hline 3. & knowledge in material resources management \\
\hline 4. & knowledge of law \\
\hline
\end{tabular}




\begin{tabular}{|c|c|}
\hline 5. & medical knowledge \\
\hline 6. & systematic and analytical thinking \\
\hline 7. & strategic thinking \\
\hline 8. & creating a vision \\
\hline 9. & creating a desired image \\
\hline 10. & work experience \\
\hline 11. & ability to handle uncertain situations \\
\hline 12. & ability to resolve conflicts \\
\hline 13. & leadership skills and ability to motivate others to change \\
\hline 14. & decision-making skill \\
\hline 15. & cooperation skills \\
\hline 16. & negotiation skills \\
\hline 17. & ability to delegate power and tasks \\
\hline 18. & time-management skills \\
\hline 19. & knowledge of the English language \\
\hline 20. & stress-management skills \\
\hline 21. & emotional intelligence \\
\hline 22. & communication \\
\hline 23. & foreseeing the consequences of one's choices \\
\hline 24. & taking responsibility for one's choices \\
\hline 25. & ethical behaviour \\
\hline 26. & focus on results \\
\hline 27. & assertiveness \\
\hline 28. & courage \\
\hline 29. & authority \\
\hline 30. & creativity \\
\hline 31. & trust in employees \\
\hline 32. & ability to build and manage a team \\
\hline 33. & focus on the development of competences \\
\hline 34. & ability to motivate employees \\
\hline 35. & focus on quality \\
\hline 36. & taking care of the wellbeing of the client \\
\hline 37. & personal culture \\
\hline 38. & consistency in action \\
\hline
\end{tabular}

\section{Source: own research.}


In the next phase of the key competency model building process, according to methodology 20/80, a hierarchy of competences was developed. Detailed results are presented in Table 3.

Table 3. Hierarchy of competences according to healthcare managers

\begin{tabular}{|c|c|c|c|c|c|c|}
\hline No. & Competence name & $\begin{array}{l}\text { Cumu- } \\
\text { lated \% } \\
\text { of the } \\
\text { number } \\
\text { of com- } \\
\text { petences }\end{array}$ & Points* & $\begin{array}{l}\text { Cumu- } \\
\text { lated } \\
\text { number } \\
\text { of points }\end{array}$ & $\begin{array}{l}\text { Cumu- } \\
\text { lated \% } \\
\text { of the } \\
\text { number } \\
\text { of points }\end{array}$ & $\begin{array}{l}\text { Subset } \\
\text { of com- } \\
\text { petences }\end{array}$ \\
\hline 1 & 2 & 3 & 4 & 5 & 6 & 7 \\
\hline 1. & $\begin{array}{l}\text { Knowledge in human } \\
\text { resources manage- } \\
\text { ment }(P)^{\star \star}\end{array}$ & 4.17 & 34 & 34 & 11.30 & \multirow{5}{*}{ A } \\
\hline 2. & Negotiating skills (P) & 8.34 & 32 & 66 & 21.93 & \\
\hline 3. & Work experience $(P)$ & 12.51 & 29 & 95 & 31.56 & \\
\hline 4. & $\begin{array}{l}\text { Ability to determine } \\
\text { strategy }(P)\end{array}$ & 16.68 & 25 & 120 & 39.87 & \\
\hline 5. & $\begin{array}{l}\text { Ability to communi- } \\
\text { cate clearly }(P)\end{array}$ & 20.85 & 24 & 144 & 47.84 & \\
\hline 6. & Teamwork skills (S) & 25.02 & 19 & 163 & 54.15 & \multirow{7}{*}{ B } \\
\hline 7. & $\begin{array}{l}\text { Ability to delegate } \\
\text { tasks }(P)\end{array}$ & 29.19 & 17 & 180 & 59.80 & \\
\hline 8. & $\begin{array}{l}\text { Knowledge of the } \\
\text { surroundings }(P)\end{array}$ & 33.36 & 16 & 196 & 65.12 & \\
\hline 9. & $\begin{array}{l}\text { Problem-solving } \\
\text { skills }(P)\end{array}$ & 37.53 & 15 & 211 & 70.10 & \\
\hline 10. & Authority (S) & 41.70 & 11 & 222 & 73.75 & \\
\hline 11. & Courage $(\mathrm{O})$ & 45.87 & 10 & 232 & 77.08 & \\
\hline 12. & $\begin{array}{l}\text { Resistance to stress } \\
\text { (O) }\end{array}$ & 50.04 & 10 & 242 & 80.40 & \\
\hline
\end{tabular}




\begin{tabular}{|c|c|c|c|c|c|c|}
\hline 13. & $\begin{array}{l}\text { Ability to build inter- } \\
\text { personal skills (S) }\end{array}$ & 54.21 & 9 & 251 & 83.39 & \multirow{12}{*}{ C } \\
\hline 14. & $\begin{array}{l}\text { Information manage- } \\
\text { ment skill }(P)\end{array}$ & 58.38 & 9 & 260 & 86.38 & \\
\hline 15. & Creativity $(\mathrm{O})$ & 62.55 & 8 & 268 & 89.04 & \\
\hline 16. & Assertiveness $(\mathrm{O})$ & 66.72 & 7 & 275 & 91.36 & \\
\hline 17. & Communication (S) & 70.89 & 6 & 281 & 93.36 & \\
\hline 18. & $\begin{array}{l}\text { General medical } \\
\text { knowledge }(P)\end{array}$ & 75.06 & 5 & 286 & 95.02 & \\
\hline 19. & Focus on goals $(P)$ & 79.23 & 4 & 290 & 96.35 & \\
\hline 20. & Ability to listen (S) & 83.40 & 4 & 294 & 97.67 & \\
\hline 21. & Personal culture (S) & 87.57 & 3 & 297 & 98.67 & \\
\hline 22. & $\begin{array}{l}\text { Ability to delegate } \\
\text { power }(P)\end{array}$ & 91.74 & 2 & 299 & 99.34 & \\
\hline 23. & $\begin{array}{l}\text { Focus on self-de- } \\
\text { velopment and the } \\
\text { development of } \\
\text { employees (S) }\end{array}$ & 95.91 & 1 & 200 & 99.676 & \\
\hline 24. & $\begin{array}{l}\text { Consistency in ac- } \\
\text { tion (O) }\end{array}$ & 100.00 & 1 & 301 & 100.00 & \\
\hline
\end{tabular}

* number of points (column 4) is an average of the indications of all respondents.

** $\mathrm{P}$ - professional competences, $\mathrm{S}$ - social competences, $\mathrm{O}$ - personality competences

\section{Source: own research.}

The data in Table 3 show that the initial list of 38 competences of an effective health manager (Table 2 ) has been minimised to 24 competences. The new set is dominated by professional competences, accounting for $50.0 \%$ of all competences required by the respondents for good job performance in managerial positions. Nearly every third of the competences (29.2\%) is social, and every fifth (20.8\%) - a personality trait.

According to the Pareto rules, the key competences are contained in subset A representing $20 \%$ of all competences. In the research project, this sub-set consists of the competences listed in Table 3 under items 1-5. However, they cannot be accepted as sufficient because it is assumed that the acceptable efficiency of management activities should be at least $80 \%$. Thus, if the manager was "equipped", i.e., shown in practice only the five competences, the efficiency of their activities would be only $47.84 \%$ (column 
6 in Table 3). Hence, their competence potential should be enriched by the competences that together will ensure the expected efficiency. As indicated in Table 3-80\% performance level equals 12 competences located in subsets $A$ and $B(80.4 \%$ in column 6 of Table 3$)$.

In the light of the obtained results, the competences listed in Table 3 under headings 1-12 should be considered as key competences. All have been evaluated. Health managers working in teams first designed the desirable states of these competences, and later self-assessed their current states. The difference between the desired state and the actual state is called the competence gap (Table 4).

Table 4. The profile of key competences in the self-assessment of healthcare managers

\begin{tabular}{|l|l|l|l|l|}
\hline \multirow{2}{*}{ No. } & \multirow{2}{*}{ Competence name } & \multicolumn{2}{|l|}{ Competence level } & \multirow{2}{*}{$\begin{array}{l}\text { Competence } \\
\text { gap }\end{array}$} \\
\cline { 3 - 4 } & & desired & current & -1.5 \\
\hline 1. & $\begin{array}{l}\text { Knowledge in human resources } \\
\text { management }\end{array}$ & 4.0 & 2.5 & \\
\hline 2. & Negotiating skills & 4.0 & 3.0 & -1.0 \\
\hline 3. & Work experience & 3.0 & 3.0 & 0.0 \\
\hline 4. & Ability to determine strategy & 4.0 & 2.0 & -2.0 \\
\hline 5. & Ability to communicate clearly & 5.0 & 5.0 & 0.0 \\
\hline 6. & Teamwork skills & 4.0 & 3.5 & -0.5 \\
\hline 7. & Ability to delegate tasks & 5.0 & 3.0 & -2.0 \\
\hline 8. & $\begin{array}{l}\text { Knowledge of the surround- } \\
\text { ings }\end{array}$ & 3.0 & 3.0 & 0.0 \\
\hline 9. & Problem-solving skills & 4.0 & 3.0 & -1.0 \\
\hline 10. & Authority & 3.0 & 3.0 & 0.0 \\
\hline 11. & Courage & 3 & 3.0 & 0.0 \\
\hline 12. & Resistance to stress & 4.0 & 5.0 & +1.0 \\
\hline
\end{tabular}

\section{Source: own research.}


In the key competences portfolio, knowledge and professional skills are in the lead (66.7\% of all competences in subsets A and B). According to the respondents, the most important competence is knowledge in the field of human resource management. This is a reasonable preference because success in managerial work is achieved through the work of the people under the manager. In this competence, a significant gap was identified in the self-assessment, which was 1.5 on the 5-point scale (Table 4). Health managers participating in the study added to the general knowledge about people management such specific competences as team collaboration, delegation, negotiation skills, and problem solving. In the latter competence, the gap was -1.0 .

Another important competence was the knowledge of the medical environment. This is a good indication because it is difficult to imagine a situation where an efficient manager does not know the environment of the entity they manage. This knowledge should make it easier to set goals and build strategies. Unfortunately, in this competence and the ability to delegate tasks, the biggest, two-tier (-2.0) competency gaps were noted. Competency deficits in the key competency portfolio were also noted in negotiating skills (-1.0) and teamwork (-0.5).

The portfolio of the key competences of the manager should be complemented by the other competences mentioned in this project in subset C. It is dominated by social competences, among which is the focus on personal and co-workers development. This is a very important competence, and its presence, however only in the tertiary subdivision of importance, means that healthcare managers see the need for continuous improvement not only of their own but also of all employees.

In the light of the competences of managers in healthcare institutions, as summarised in Table 2, objections may be raised due to a lack of competences such as analytical and systemic thinking, behavioural knowledge in the health services market, or financial management expertise. Discussions with managers involved in this diagnosis indicate that analytical and sys- 
tematic thinking have been included in competences connected to setting goals and developing strategies for action. Market behaviours are placed in competence regarding knowledge of the environment in which they see the behaviour of customers and other healthcare providers. As for the absence of financial management competence, they did not have a clear comment and explained it with the oversight or the fact that in all healthcare entities there are specialised organisational units that manage these resources. It seems, however, that an efficient healthcare manager should be "equipped" with this competence, which is extremely important under the widely criticised under-funding of all entities in the sector. It is mainly about knowledge and skills in the field of finance and budgeting.

\section{Discussion and summary}

The competence model presented in the article was based on literature sources and the practice of persons holding managerial positions at various levels of management in healthcare establishments (branches) in Warmińsko-Mazurskie Voivodeship. The identified set of key competences is largely consistent with similar sets presented in the world literature (e.g. Calhoun et al., 2008, Leotsakos et al., 2014 and Ramirez et al., 2017), which indicates analogous problems in the management of healthcare institutions but also takes into account the specific nature of the Warmińsko-Mazurskie Voivodeship.

In the proposed own model and in the models of the above-mentioned authors, knowledge of the environment was identified as a common competence. In interpreting this competence, individual authors emphasize its various components. For example, A. Leotsakos et al. $(2014$, p. 8) speak of political and social astuteness, which according to them:

- "responds to changing individual and community expectations; demonstrates responsiveness, participation and inclusiveness,

- facilitates alignment with national health reforms,

- responds to global trends, 
- interacts effectively with the media and engages with them where appropriate".

In turn, J. Calhoun et al. (2008, p. 379) describe the analyzed competence as "community orientation" and define it as "the ability to align one's own and the organization's priorities with the needs and values of the community, including its cultural and ethnocentric values, and to move health forward in line with population-based wellness needs and the national health agenda". By contrast, B. Ramirez et al. (2016, p. 13) call this competence "navigate change" and emphasize that "the key to success is leadership and competent management to navigate change".

Comparing the competence sets resulting from own research and published in the literature, the occurrence of competencies characteristic for managers managing healthcare entities in the Warmińsko-Mazurskie Voivodeship is noticed. These include competences such as resistance to stress, courage and authority, which are not articulated in competency models of other researchers. Thus, these studies complement the knowledge of competence profiles in the territorial dimension. Interestingly, such areas as strategic thinking, human resource management skills, delegation and responsibility skills, team building and management skills are emerging at the forefront of the survey, together with knowledge of the environment in which the entity operates. Yet at the same time, the biggest competence gaps were diagnosed in those competences. Thus, it seems reasonable to postulate the introduction of more curricular content enhancing the skills identified in these studies into the educational model of potential health managers. 


\section{Acknowledgements}

The paper was supported by funding from National Science Centre, Poland (grant number: 2015/17/B/HS4/02747)

\section{References}

Armstrong, M. (2000). Zarządzanie zasobami ludzkimi. Oficyna Ekonomiczna-Dom Wydawniczy ABC, Kraków.

Bellini, E., Ottaviano G.I.P., Pinelli D., \& Prarolo G. (2013). Cultural Diversity and Economic Performance: Evidence from European Regions. In: R. Crescenzi, M. Percoco (eds), Geography, Institutions and Regional Economic Performance. Advances in Spatial Science (The Regional Science Series). Berlin, Heidelberg: Springer.

Burak, A.M., Mućka, J., Ferenc, A., \& Tlappa, J. (2016). Specyfika zachowań przywódczych kadry kierowniczej współczesnej ochrony zdrowia. Pielęgniarstwo i Zdrowie Publiczne, Tom 5, Nr 1, ss. 53-65.

Calhoun, J.G., Arbor, A., Sinioris, M.E., Wainio, J.A., Peter, W., Butler, P.W., Griffith, J.R., \& Warden, G.L. (2008). Development of an Interprofessional Competency Model for Healthcare Leadership. The National Center for Healthcare Leadership. Journal of Healthcare Management, No 53 (6) November/December, p. 378 [online], http:// cahme.net/files/healthsector/CalhounDevelopmentofInterprofessionalCompetency. pdf, access 10.10. 2017.

Czapla, T. (2005). Ukierunkowanie globalne relacji organizacji z otoczeniem In W. Błaszczyk (ed.), Metody organizacji i zarządzania. Kształtowanie relacji organizacyjnych. Warszawa: Wyd. Nauk. PWN. 
Edwards, N., Marshall, M., McLellan, A., \& Abbasi, K. (2003). Doctors and managers: a problem without a solution? BMJ, vol. 326, pp. 609-610 [online], http://pubmedcentralcanada.ca/pmcc/articles/PMC1125518/pdf/609.pdf, access: 12.11.2017.

Furtak, M., Książek, P., Rzemek, C., \& Zdrojkowski, J. (2010). Kształcenie menedżerów jako kluczowy czynnik efektywnego zarządzania jednostkami ochrony zdrowia. Zdrowie Publiczne, Nr 3 (120), pp. 213-217.

Jakubek, E., Głowacka, D., \& Matecka, M. (2012). Komunikacja jako element kompetencji zawodowych pracowników służby zdrowia. In R. Lewandowski, M. Kautsch (ed.), Przekształcenia strukturalne i społeczne w ochronie zdrowia. Przedsiębiorczość ¡ Zarządzanie Vol. XIII, Issue 5, pp. 167-182.

Jankowiak, R. (2011). Kompetencje zarządzającego niepublicznym zakładem opieki zdrowotnej. In. R. Lewandowski, R. Walkowiak (ed.), Zarządzanie w ochronie zdrowia. Problemy wybrane. Olsztyńska. Olsztyn: Wyższa Szkoła Informatyki i Zarządzania im. Prof. T. Kotarbińskiego, pp. 123-135.

Kautsch, M. (2015). Charakterystyka zarządzania zakładem opieki zdrowotnej. In Zarządzanie w opiece zdrowotnej. Nowe wyzwania. Warszawa: Wolters Kluwer, pp. 88-106.

Kostecka, A. (ed.) (2016). Nowoczesny menedżer ochrony zdrowia. 18 kluczowych kompetencji. Warszawa: Wydawnictwo: WIEDZA I PRAKTYKA.

Leotsakos, A., Petsanis, K., Zhao, H., Moss, R., Monina, N. (2014). Leadership Competencies Framework on Patient Safety and Quality of Care (DRAFT). World Health Organization, Geneva, Switzerland, pp. 2-3 [online], http://www.who.int/servicedeliverysafety/areas/health-service-delivery-for-leaders.pdf, access: 4.10.2017. 
Lewandowski, R.A. (2011). Wpływ cech socjodemograficznych na poziom zaufania w ochronie zdrowia In R. Walkowiak, R. Lewandowski (ed.). Zarządzanie w ochronie zdrowia. Finanse i zasoby ludzkie (119-134). Olsztyn: Olsztyńska Wyższa Szkoła Informatyki i Zarządzania im. Prof. T. Kotarbińskiego.

Littwin, K.I. (2013). Rola profesjonalistów medycznych w zarządzaniu szpitalem In R. Lewandowski, M. Kautsch, Ł. Sułkowski (ed.), Współczesne problemy zarządzania w ochronie zdrowia z perspektywy systemu i organizacji. Przedsiębiorczość i Zarządzanie, Vol. XIV, Issue 10, pp. 205-214.

Matecka, M., Sielska J., \& Dąbrowska, E. (2015). Kompetencje menedżera podmiotu leczniczego. Zeszyty Naukowe Uniwersytetu Szczecińskiego, Nr 875, Problemy Zarządzania, Finansów i Marketingu, Nr 41, T. 2, pp. 293-304.

Ramirez, B., West, D.J. Jr., Aaronson, W.E., \& Ramirez, Ch.L. Global Health Management Competencies: A Framework For Effective Management Training. The Healthcare Leadership Alliance and the American College of Healthcare Executives 2017 [online] http://vz.truni.sk/fileadmin/Dokumenty/konferencie/2016/Kolokvium_2016/ Bernardo_Ramirez_colloquium.pdf, access 14.11.2017.

Rosińska, R. (2013). Kształcenie menedżerów dla podmiotów leczniczych. Przedsiębiorczość i Zarządzanie, Vol. XIV, Issue 4, pp. 9-20.

Swayne, L.E., Duncan, W.J., Ginter, P.M. (2012). Zarządzanie strategiczne w ochronie zdrowia. Wolters Kluwer Polska, Warszawa.

Test kompetencji kierowniczych kadry polskich szpitali (2015). Akademia ochrony zdrowia - Edumetriq, Sopot, www.edumetriq.pl, access 10.05.2017.

Walkowiak, R. (2007). Zarządzanie zasobami ludzkimi. Kompetencje. Nowe trendy. Efektywność. Toruń: Dom Organizatora - TNOiK. 
Watson, T.J. (2001). W poszukiwaniu doskonałego zarządzania. Warszawa: Wydawnictwo Naukowe PWN.

Yen-Ju, Lin, Pei-ShanChiang, Yu-Wen, Liao, Sheng-JoWang, Ai-Tzu, Li (2011). Constructing Executive-level Health Manager's Competency Model-A Case Study of the Health Examination Center at a Teaching Hospital in Central Taiwan. 2nd International Conference on Education and Management Technology. IPEDR, vol. 13, pp. 89-90, IACSIT Press, Singapore; http://www.ipedr.com/vol13/17-T00028.pdf. 